\title{
The Teaching Model Reform of the Local Colleges and Universities under the Background of MOOC Era
}

\author{
Liu Qing \\ Network information center \\ Qilu University of Technology \\ JiNan China \\ e-mail:liuqing@qlu.edu.cn
}

\begin{abstract}
As a new teaching mode, MOOC has a variety of advantages beyond the traditional teaching mode, which has produced profound influence on the traditional teaching mode. Today,great changes have taken place in student groups and social needs, the traditional teachingmode has been difficult to adapt to the demands of a new age.This articleanalized the enlightenment of teaching reform from the MOOC,andprobes a new teaching mode between theMOOCand the traditional teaching mode,by studying the contradictionsbetween the talents training goal of local universities with the current teaching mode.
\end{abstract}

KeyWords-MOOC(MassiveOpe nOnline Courses),Localcolleges and universities,Traditional teaching mode, SPOC(Small Private Online Course)

With the development of market economy,the higher education of our country has made the transition from elite to mass. At present, the local colleges accounts for more than $90 \%$ of the total number of the nation undergraduate university,it has become the main force of Chinese higher education.In a number of local colleges generally there are some problems, such as, teaching means aging, old research facilities, faculty development imbalance, limited teaching resources, etc.,and all the factors listed above resulting in the teaching mode has been no breakthrough.

In 2011, massive open online courses-MOOC arise,it's quality of the curriculum resources, independent and individualized learning, equality and mutual assistance relationship between teachers and students,MOOC swept the world in a short period of time,it posed a challenge to higher education around the world, and promoting the teaching modeto speed up the pace of reform in colleges and universities. As a new kind of mode,the MOOCOpened a new door for the local colleges and universities teaching mode reform.

\section{I.THE MAIN PROBLEMS OF THE TRADITIONAL TEACHING} MODE IN LOCAL COLLEGES

Combined with the talentstraining of local universities and regional economic society, is not only the inevitable demand for regional development of higher education, but also their own development. Therefore, based on local economic development and market demand, training applied talents with practical ability and innovation ability, has become the local colleges and universities personnel training goal.However, in the vast majority of local colleges in the way of teaching and ignores the cultivation of students' comprehensive ability. The same teaching contents are difficult to highlight the regional characteristics,and the traditional teaching mode cannot satisfied the demand of the talents training target in the new period.

\section{A. Knowledge oriented teaching mode is contradictory with training practical ability}

Along with the production of teaching activities, books, teachers, classroom centered teaching mode has been the dominant factor. At present, the teaching activity oflocal colleges and universities basically followed the traditional mode of classroom teaching. In the process of teaching too much emphasis on imparting knowledge, the knowledge oriented teaching mode ignores the cultivation of students' other abilities. Applied talents should pay more attention to training students' ability, however, relying on teaching knowledge cannot cultivate students' ability,it is formed through repeated practice. This kind of comprehensive ability not only include knowledge acquisition, also includes the emotions, attitudes and values, and this is the students individual internal behavior of self-improvement.

The university undergraduate teaching process should not only reflect the cognitive process of studying scientific truth, should reflect the cognitive process of found scientific truth, otherwise the teaching process is not complete.[1] Psychological research shows that, in the case of cognitive dissonance, people always want to seek a new balance of cognition, resulting in the desire to explore,in view of this, the teacher should not only impart knowledge, but also to guide students to explore knowledge.Confucius divided the learning process into four stages: learning, thinking, exercise, practice, but we often stay in the first three stages. Students acquire knowledge relying too much on teachers, lack of exploration and practice, these are unfavorable to the cultivation of ability.

\section{B. The traditional knowledge system is contradictory withinnovation ability}

According to the relationship between teaching and scientific research in universities, Chinese higher education colleges and universities is now divided into three categories: 
Research universities, teaching-research universities and teaching universities.Research universitiesare dominated by the "985 Project" and "211 Project" Universities, while teaching universities take the local colleges and universities as the main body. In general,the key universities always stay in the forefront which in course content updates and construction of teaching material. Local colleges and universities due to their weak foundation and limited teaching resources, textbooks become their main source of knowledge,however, the lag phenomenon long-standing teaching materials in colleges and universities. With the progress of era and the development of science, part of the textbook knowledge aging, especially some practical, fast updates disciplines, such as computer science, medicine, law and so on disconnect situation is more serious. No matter in which field, to cultivate creative talents, rely on the old knowledge system is not feasible.

\section{The homogeneity of the teaching contentis contradictory withRegional characteristics}

Local colleges and universities is different from the general research university and Career Technical College, its position in the local society, determines that it must be oriented to the development of local economy construction and industry, to cultivate applied talents whom with regional characteristics.Under the trend of popularization of higher education, local colleges and universities in the professional setting on the pursuit of "big" and "full", lead to homogeneity serious. In fact, different regions are different in the geographical environment and humane environment, industry structure, Therefore, professional setting should also have regional characteristics, such as construction, agriculture, tourism, arts and other professional. However, in the teaching content, there is no essential difference between the local colleges and universities. The same disciplines and similar content, resulting in students' knowledge structure are very similar to each other which in the same Professional, and lack of competitive advantage.

\section{II..MOOC BRINGS TO THE TRADITIONAL TEACHING MODE REFORM OPPORTUNITY}

MOOCprovided a rich media, rich resources of learning style, so that learning became more personalized, greatly enhance the efficiency of learning, make students have more opportunities to cultivate comprehensive qualities. MOOC is like a breeze, has poured into the new vigor for the reform of traditional teaching mode.

\section{A. Autonomous learning and the depth of interaction is beneficial to the development of the learning efficiency and ability}

First of all, the MOOC is more suitable for the requirement of autonomous learning than the traditional classroom teaching. In the traditional classroom teaching mode, the students listen to the teacher, and they lack of learning initiative and targeted, this teaching mode cannot adapt to all the students way of thinking, the efficiency is not high.MOOC give students full rights in autonomous learning, students can control over the whole learning
process.The teaching video is usually between 8 - 12 minutes of smallpieces, These video information content is rich, dense, students can pause, review anyknowledge point, to facilitate learners to use fragments of time at anywhere.MOOC gives students full and personalized learning experience, students can independently develop the curriculum goal, determine the learning process, and learning efficiency is also increased accordingly.

Secondly, the MOOC provides a more interactive way between teachers and students, to train students' ability.MOOC has more interactive way, not only the interaction between teachers and students, also the interaction between students.MOOC according to the settings in the game clearance, also set up many quizzes,onlyall the questions right be done students should be allowed to continue to watch the video,if there are any questions, they can put them on the platform of MOOC, there will be eventually have the answer from a teacher or study partner. [2]

Therefore,MOOC can not only let students learn knowledge, but also allow them to explore knowledge, even produce knowledge. When students find their own "know-how" in the independent and interactive learning, their learning ability, the ability to discover and solve problems even practical ability will get all-round development.

\section{B. An equal relationship between teachers and students is good for cultivating students' innovation ability}

MOOC makes the relationship between teachers and students become more closely and harmony.Away from the monotony of classroom lectures, the personality of studentscan be fully released, in this independent, cooperation and explore learning environments, the students' minds become more independently,andtheir innovation consciousness also get exercised,when they exchanging their views with teachers.

MOOC help students to develop the international view, because ithas worldwide famous universities courses, and all courses are carefully designed,Local college students have access to the latest academic achievements, as well as to master the new frontier discipline. Theviewchanges ideas, in the era of globalization,only to let the students to stand in the international platform, then the students' thinking ability and creation ability can obtain the better development.

\section{Creating localized MOOCto show the features of regional talents}

The theory of educational economics thinks that the economic structure has an interdependent relationship with education structure. In recent years, with the development of local economy and the adjustment of industrial structure, talents demand also presents certain regional characteristics.Therefore, we should buildthe open teaching ideas,move the classroom into the workshop and laboratory, combining the local pillar industry and university courses to create localized MOOC courses. The teaching contents should include the theoretical knowledge and skills, and the teaching way close to the actual production and 
operation of enterprises.Expanding the function modules oftheMOOC, such asclassifying the MOOC learners to build an open communication platform . Through this platform, experienced staff can communicate with students, practitioners can share experienced technical practice, students can share the theoretical knowledge, which is beneficial to the enterprise and the local university.

\section{THE NEW DIRECTIONS OF LOCAL UNIVERSITY TEACHING MODE REFORM ARE COMBINED WITH THE MOOC AND TRADITIONAL CLASSROOM}

Although traditional teaching cannot be compared with the advantages of MOOC, but this does not mean that it can replace the University classroom.MOOC also has many problems, it is not suitable for all courses, the problem of exam credibility has been difficult to solve, and there are also problems in the controllable andsustainability of the learning process.In addition to the talent training, the university also has the other functions,such as: scientific research, serve the society and cultural inheritance,which areMOOC can not to do.Therefore,the new directions of local university teaching mode reform are combined with the MOOC and traditional classroom.

\section{A. The reform of teaching contents}

The curriculum design of the MOOC is novel and widely. The reform of teaching contents can use the MOOC reference model, updating the teaching contents and curriculum systemfrom the perspective of internationalization, drawing lessons from the foreign excellent teaching resources,combined with the basic knowledge of the textbooks and the academic frontiers,online teaching material also can be integrated into the curriculum contents.This kind of comprehensive curriculum, which broken the old discipline boundaries, it is not only guarantee the basic knowledge of students' learning, but also broaden the students' cognitive domain, it is helpful to cultivate innovative talents to meet the demand of times development.

\section{B. The reform of assessment way and contents}

The traditional assessment way are basically completed by theexaminationpaper, it exaggerated the value of scores. This way of assessment can't reflect the integrity of the teaching process and the students' individual differences.According to the learning objectives of different disciplinestoget the diversification of the performance structure through a variety of assessment methods, so as to ensure a more complete and fair teaching evaluation. Themodern society need other abilities, such as the ability to find ,analyze and solve problems, and the literature retrieval ability, the team cooperation ability andmany abilities in otheraspects, especially the innovative thinking ability, these are not reflected in the assessment.Modern society needs the other abilities, such as: fault-finding capability, the ability to analyze and solve problems, and literature retrieval ability, team cooperation ability, especially the innovation ability, these abilities cannot be reflected in the traditional examination.

Referencing the evaluationway ofMOOC, combining with online and offline examination, and practicing these online objective itemsthrough in-class quizto ensure that students master the basic knowledge, subjective topicscan be evaluated through group discussion in the classroom.Stage assessment can test the students'learning ability and the quality of teaching,thus help to revise teaching activities.Examination contents should involve a number of application questions which have not standard answers,science and engineering students can design case, liberal arts students can through the case analysis or papers, so that to test students' ability of using knowledge and innovation ability.[3] Yale university, for example,many exam papers there is no correct answer only, its purpose is to cultivate students' independent thinking, critical thinking, rigorous analysis, and innovative ability. [4]

\section{The reform of teaching feedback way}

The complex large data which related with interactive online learning behavior will be automatically captured and recorded.According to estimates, the data which MOOC platform collected in a few weeks, is almost the sum of traditional classroom teaching for decades. [5] These vast amounts of real-time data will reflect the students learning situation. For example, the video watching time and frequency, the correct rate of online test, the key words which studentsdiscussed. For the teachers, they can analyze the problems which in the learning process from these data, alsoadjust the curriculum and improve teaching way;for thestudents, they can also find their own problems. Big data can be according to the tracking of the students online learning behavior to push personalized learning contents, so that help themto improve learning accurately and effectively .

\section{THE CONCLUSION}

In the trend of globalization and modernization,local colleges and universities are limited in the resources and talents, to cultivate applied talents with practical ability and innovation ability, we must update the education idea, reform the teaching mode in order to meet the need of education and economic development. Although MOOCcannot replace the traditional teaching completely, but from its development we can see the future development direction of education. Therefore, local colleges and universities only based on the existing teaching mode, and learn from the advantages of MOOC, the teaching reform can becarried out more smoothly.

\section{REFERENCES}

[1] Zhang jianlin,"Bachelor's degree teaching process integrity and research learning”, The research of Higher Education , February2005.

[2] Xu qian,"MOOC can change the classroom or not",Shanghai Education,2013,p.28

[3] Dou zhijie,Nie ying, “The idea to promote the reform of local colleges and universities to research teaching examination”,Modern education management,2013, pp.56-69 
[4] Liu rong,"The status quo comparison and enlightenment of domestic and foreign university examination system”, The northern economic and trade, June,2009.

[5] Wu wenjun,Lv weifeng, "The massive open online education in the era of big data”, Computer education, January,2013 